\title{
Research on the Cultivation of Innovative Entrepreneurial Talents
}

\author{
Geng Ruixia ${ }^{1}$, Li Xudong ${ }^{2}$ \\ ${ }^{1}$ Xijing University, Xi'an, Shaanxi, China, 710123 \\ ${ }^{2}$ Xi'an Huayu University Logistics Service Co., Ltd, Xi'an, Shaanxi, China, 710123
}

Keywords: innovation and entrepreneurship; talent cultivation; measures

\begin{abstract}
The purpose of cultivating innovative entrepreneurial talents is to respond to the strategic goal of "mass entrepreneurship and innovation" by the Chinese government, which requires the joint efforts of the Chinese government, colleges and universities and enterprises to foster innovative and entrepreneurial talents. As "mass entrepreneurship and innovation" has set off a trend, China's central government and local governments have issued a series of preferential policies to promote and foster innovative entrepreneurial talents. With the urgent need of entrepreneurial talents, colleges and universities pay more and more attention to the cultivation of innovative and entrepreneurial talents. Based on the problems of innovation and entrepreneurial talent cultivation in colleges and universities, this paper puts forward corresponding measures for the cultivation of innovative entrepreneurial talents in Chinese colleges and universities.
\end{abstract}

\section{Introduction}

The cultivation of entrepreneurial talents is to respond to the national strategic policy, and Chinese colleges and universities establish the talent training mechanism to enhance the entrepreneurial ability of entrepreneurial talents. So, this paper is of great theoretical significance for the research of entrepreneurial talent cultivation mechanism. For China's current form, innovation and entrepreneurship education is not limited to the fields of management and economics. It will involve a variety of disciplines, such as sociology and pedagogy. So, the training mechanism of Chinese universities for entrepreneurial talents must be constantly adjusted. Colleges and universities need to combine theory with practice to cultivate students' entrepreneurial ability and sense of entrepreneurship at a deeper level.

\section{Key Issues of Innovation and Entrepreneurship Training}

\subsection{Problem of education concept}

The current education concept and system of some universities in China still have a very heavy planned economy brand, and the education model is still lacking for students' personalized cultivation. This phenomenon leads to poor creativity and innovative ability, especially in the field of innovation and entrepreneurship. The current teaching model still lacks the positive atmosphere of students, and the consciousness and hospital of innovation and entrepreneurship are not strong.

\subsection{Problem of teachers' innovation ability}

The ability to cultivate students' innovation and entrepreneurship is inseparable from the guidance and cultivation of entrepreneurial mentors. Therefore, the innovative training ability of innovative mentors is an important factor. However, there is a shortage of teachers resources in some colleges and universities in China. Most entrepreneurial mentors are taught by other subjects. This phenomenon leads to the lack of time and energy for many college tutors to cultivate innovative and entrepreneurial talents, and also has no energy to innovate teaching models for innovative entrepreneurial talent cultivation. 


\subsection{Low practical ability of students}

Many college students are still influenced by the traditional education. They attach great importance to theoretical knowledge and practice operation. This traditional education model will cause many students to be reluctant to practice.

This situation will lead to the students in the process of starting a business, which will lead to the failure of entrepreneurship.

\section{Improve the National Policy Guarantee Mechanism}

\subsection{Create a good environment}

The Chinese government should provide support to innovation and entrepreneurship students from the aspects of policy and capital so as to create a good environment for entrepreneurship. It is mainly possible to support the entrepreneurship of college students through the following aspects: First, the Chinese government encourages college students to start their own businesses by establishing and improving innovation and entrepreneurship policies. And co-founding various entrepreneurship competitions with universities. At the same time, it will provide a platform for college students to exchange and learn innovation and entrepreneurship. Second, local governments can host local entrepreneurship competitions locally. The local government has continuously enriched and improved the entrepreneurial experience of college students through various innovation and entrepreneurship practice activities and competitions. The local government will increase the awareness of innovation and entrepreneurship of college students by constantly creating a good environment for innovation and entrepreneurship, and then guide the college students to the path of innovation and entrepreneurship.

\subsection{Set up special funds for college students' entrepreneurship}

The Chinese government has introduced policies to guarantee the support of college students' entrepreneurial funds. At the same time, it can alleviate the concern of college students' innovation and entrepreneurship. Although the current Chinese government has the funds to support and encourage college students to start their own businesses, these financial support is still insufficient. The Chinese government should increase the financial input of college students' entrepreneurship and set up special funds to further standardize and improve the policy of supporting the innovation and entrepreneurship students, and improve the operability of the policy. The Chinese government has adopted policy documents to promote the attention of the whole society. And then improve the college students' entrepreneurial support system.

\section{Improve University Entrepreneurship Education Level}

\subsection{Improve the education curriculum system}

The current entrepreneurship education course in Chinese universities is still dominated by entrepreneurial theory quality and entrepreneurial awareness cultivation. But the main way to cultivate innovative and entrepreneurial talents is practical training. So, it is very important to perfect the education curriculum system. Chinese colleges and universities should perfect the education system curriculum, and improve students' entrepreneurial awareness, psychological quality and entrepreneurial knowledge and skills through education. The education system of innovation and entrepreneurship in colleges and universities should be improved with the foundation of our school, curriculum setting, practical activities and teaching methods. At the same time, universities must renovate the traditional education teaching concept, break the humanistic barriers between disciplines, and pass comprehensive education training to students.

\subsection{Strengthen entrepreneurial practice}

Innovation and entrepreneurship education is a highly practical course. Chinese colleges and universities must strengthen the cultivation of practical operation when cultivating talents of this 
type. The practice of teaching can be enhanced through training centers and technology incubators. At the same time, universities can conduct education activities in various forms. For example, lectures, training, publicity, competitions and other ways to stimulate entrepreneurial enthusiasm of college students. In this way, the college students should have a good understanding of the skills needed for their own business, and make up their own weaknesses after class. Chinese universities should build a practical platform for entrepreneurship training. Through this platform to test and train the professional knowledge and skill level of college students, let the participating college students have a clear understanding of the short board of their own business. The improvement and strengthening of college students' practical activities is importance to the cultivation of innovative entrepreneurial talents. By allowing students to experience or participate in entrepreneurial internships, students can experience the hardships of entrepreneurship in advance. It is very helpful to cultivate innovative and entrepreneurial talents in colleges and universities.

\subsection{Establish a start-up park and a result incubator base}

Innovation and entrepreneurship teaching base, practice base and training base are very important to the cultivation of college students' innovation and entrepreneurship practice. So, Chinese universities should create entrepreneurship parks and incubation bases to foster more and more students participating in innovation and entrepreneurship practice. In these entrepreneurial parks, corresponding organizational management institutions should be established and responsible for daily business activities and guidance. The policy information of all aspects should be collected to provide consulting services for innovation and entrepreneurship students. Colleges and universities should establish incubation bases for entrepreneurial achievements, and strengthen the transformation of scientific and technological achievements into market forces. Chinese colleges and universities should actively encourage teachers to set up the education research institute, encourage students to set up various entrepreneurial associations, and make full efforts to cultivate innovative talents.

\subsection{Improve the school-enterprise collaborative talent training mode}

Local colleges and universities should actively cooperate with enterprises to foster innovative and entrepreneurial talents. Through the joint training mode with the enterprise, the new talent training mode is adopted to promote the cultivation of innovative entrepreneurial talents. Schoolenterprise alliance can make full use of local universities, enterprises and other resources to conduct different kinds of practical teaching for students. In this way, different cultivation methods of universities and enterprises can be brought into play to provide students with a practical platform for theoretical connection. So, through strengthen the connection between schools and enterprises, students can be more interested in the practical ability while accepting the theoretical knowledge of innovation and entrepreneurship. School-enterprises jointly establish entrepreneurial practice bases, co-guide talents, and carry out entrepreneurial exchanges and other ways to cultivate entrepreneurial talents. Colleges and universities continuously improve the school-enterprise collaborative talent training mode.

\section{Conclusion}

Promoting innovation and entrepreneurship practice is the key link of cultivating innovative entrepreneurial talents in colleges and universities. Colleges and universities should strengthen innovation and entrepreneurship training programs, strive for government and enterprise support, and promote the combination of industry-university-research and research to promote innovation and entrepreneurship practice. The practice activities such as internship, training and experiment should be added to strengthen the training of innovation and entrepreneurship skills, and the training of innovation and entrepreneurship skills throughout the professional teaching process. 


\section{References}

[1] Etzkowitz H, Zhou C. Introduction to special issue Building the entrepreneurial university: a global perspective. Science \& Public Policy (2008), p. 627 - 635

[2] Drongelen K V, Bilderbeek J. R \& D performance measurement: more than choosing a setof metrics. R \& D Management (2005), p. 35 - 46

[3] Finke R A, Slayton K. Explorations of creative visual synthesis in mental imagery. Memory \& Cognition (2008), p. 252-257

[4] Csikszentmihalyi M. Implications of a systems perspective for the study of creativity. Handbook of Creativity (2009), p. 313 - 338

[5] Amabile T M. Motivating Creativity in Organizations: On Doing What You Love and Loving What You Do. California Management Review (2014), p. 39 - 58

[6] Robinson, P. B. Sexton, E.A. The Effect of Education and Experience on Small and Entrepreneurial Success. Journal of Business Verturing (2014), p. 141 - 156

[7] Potter J. Entrepreneurship and Higher Education: Future Policy Directions. Sourceoecd Education \& Skills volume (2013), p. 422 - 448 